\title{
Is there a General Interest hors la loi?
}

Pål Wrange ${ }^{1}$

\begin{abstract}
A presentation at the Biannual Conference of the European Society of International Law, Paris, 2006.
Published in Select Proceedings of the European Society of International Law. Volume 1, 2006, (Hélène Ruiz Fabri , Emmanuelle Jouannet, and Vincent Tomkiewicz eds, Portland: Hart Publishing , 2008) 279-292.
\end{abstract}

\section{International Law and the General Interest I}

The term 'interest' is entrenched in political and diplomatic discourse since at least the late $16^{\text {th }}$ century. It is, in fact, one of the constitutive concepts in politics, which would be difficult to imagine without 'interest'. ${ }^{2}$ And equally so international law. ${ }^{3}$

Now, what sort of interest does international law serve - specific ${ }^{4}$ interests or the general interest? For such a question, most people would probably look to the multilateral 'law-making'. ${ }^{5}$ conventions. And the purpose of such conventions can be ascertained, presumably, from their preambles. The 1907 XIII Hague Convention concerning the rights and duties of neutral powers in naval war was fairly modest in its aspirations. The preamble declared that the Convention was set out ' $[\mathrm{w}] \mathrm{ith}$ a view to harmonizing the divergent views' and that it was 'undeniably advantageous to frame, as far as possible, rules of general application to meet the case where war has unfortunately broken out'. The Covenant of the League of Nations, in a short preamble, was more ambitious and declared that it had been created ' $\mathrm{I}] \mathrm{n}$ order to promote international co-operation and to achieve international peace and security.' In the UN Charter, 'the peoples' famously declared themselves 'determined to save succeeding generations from the scourge of war, ... to reaffirm faith in fundamental human rights ... to establish conditions under which justice and respect for the obligations .. of international law can be maintained, and to promote social progress and better standards of life in larger freedom.' These goals undoubtedly sound like general interests. Even such a technical treaty as the Vienna Convention on the Law of Treaties believes that 'the codification and progressive development of the law of treaties achieved in the present Convention will promote the

\footnotetext{
${ }^{1}$ Principal Legal Advisor at the Ministry for Foreign Affairs and Guest Lecturer at Stockholm University. The views presented in this text are not necessarily attributable to the Swedish Government

2 See the articles under the rubric 'Interesse' in Brunner, Contze \& Koselleck (eds), Geschichtliche Grundbegriffe III (KlettCotta, 1982) 305 et seq, in particular Reinhart Koselleck, 'Der Interessebegriff im Wandel des sozialen und politischen Kontextes', at 344 et seq, Jörg Fish, "'Interesse” im Wörterbüchern und Lexika vom 16. bis zum frühen 20.

Jahrhunder', 308 at 317 Ernst Wolfgang Orth, 'Hauptakzente des Interessebegriffs vom 16.bis ins 19. Jahrhundert', 318 at 321.

${ }^{3}$ The idea that rules of international law came out of a 'balancing' of or compromise between various interests was a cliché in, for instance, the traditional law of neutrality. See, for example, Erik Castrén, The Present Law of $W$ ar and Neutrality (Helsinki, 1954) 440. More generally, see Bin Cheng, General Principles of Law, as applied by International Courts and Tribunals (republished 1987) 130 \& 132. More recent areas of international law, such as human rights law, do not fit nicely into that figure of thought, and the term 'value' has become more prevalent in international legal discourse in later years. See, for example, Erika De Wet, 'The International Constitutional Order' (2006) 55 ICLQ 51. PierreMarie Dupuy also seems to prefer values to interests in describing what it is that keeps the international legal community together. See Pierre-Marie Dupuy, 'Unité de l'ordre juridique international: Cours general de droit international public (2000)' in (2002) 297 Receuil des Cours 9 at 400-401 compared with 88.

${ }^{4}$ I take it that the organizers by 'specific interest' means something similar to 'special interest' - a derogatory term in American politics - and 'particular interest' - a venerable term of political philosophy. Ernst Wolfgang Orth, 'Hauptakzente des Interessebegriffs vom 16.bis ins 19. Jahrhundert', in in Brunner, Contze \& Koselleck (eds), Geschichtliche Grundbegriffe III (Klett-Cotta, 1982) 318 at 329, where there is a reference to Abbé Sieyès. In fact, in the French language version of the program, it is indeed the term 'intérêt particulier' that is used.

${ }^{5}$ A search on Google provided 43100 hits for the two terms 'general interest' and 'international law'. They concerned various areas of international law, including investment law, international humanitarian law, international criminal law and, quite commonly, human rights law. The 'general interest' was used to designate the interests of a national body politic (states) as well as various entities beyond or above the state, such as 'humanity'.
} 
purposes of the United Nations set forth in the Charter, namely, the maintenance of international peace and security, the development of friendly relations and the achievement of co-operation among nations.' The preamble of the Rome Statute of the International Criminal Court, the result of many benevolent aspirations, is replete with references to the general good: The parties are 'Conscious that all peoples are united by common bonds, their cultures pieced together in a shared heritage, and concerned that this delicate mosaic may be shattered at any time, Mindful that during this century millions of children, women and men have been victims of unimaginable atrocities that deeply shock the conscience of humanity, /... and/ Determined to put an end to impunity for the perpetrators of these crimes and thus to contribute to the prevention of such crimes'.

Evidently, it is the view of international law, or at least the drafters of the relevant conventions will have us so believe, that international law does serve the general interest. ${ }^{6}$ And the aspirations have become bolder and more eloquent over time. Is that a true picture?

Before I turn to that question - which I will answer only indirectly - let me say a few words about my experience of the role of international law in the decision-making process in foreign policy.

\section{International law in the policy-making process}

That role can be described differently, for example: international law is a framework for international politics, it is a tool-box for day-to-day policy and it is also a good in itself, as the basis of a rule-based international $\operatorname{order}^{7}$ (which the European Union strives for in the European Security Strategy). ${ }^{8}$

But what it all boils down to is, perhaps, whether a state will adopt the position recommended in good faith by its legal adviser even when that is contrary to its perceived interests. For sure, the international legal norm is never determinate. ${ }^{9}$ However, that does not mean that the normative words have no controlling force. And the question is whether that force will be stronger than other forces. The answer to that more pointed question is not simple: The role of international law depends on the determined policy of the state, the mind-set of the decision makers, the bureaucratic culture of the foreign

\footnotetext{
${ }^{6}$ This is no doubt also the view of many commentators. See, for instance, Christine Chinkin, Third Parties in International Law (Oxford, Clarendon Press, 1993) 291-292.

${ }^{7}$ I will briefly explain infra that I do believe that the existence of an international legal system is a good, despite the fact that the present one has severe deficiencies.

${ }^{8}$ I have compared the European Security Strategy of 2003 (ESS) with the US National Security Strategy of 2002 (NSS) in a presentation at the conference 'Comparative Visions of Global Public Order' at Harvard Law School, 5 March, 2005.

To put it briefly for the present purposes: Both are liberal; they put democracy, human rights and freedom - a word that is particularly common in the NSS - at the centre, and assume that peace will grow, as more countries become liberal democracies. The starkest differences between the two security strategies concern the basis for the order. The NSS states, somewhat curiously, that the US will try to create a 'balance of power' that favors human freedom, and that involves 'good relations among the great powers' and 'cooperative action with the other centers of global power'. The US will pursue a distinctive American brand of internationalism, based on its power. The ESS, by contrast, explicitly repudiates the concept of balance of power. It seeks 'a stronger international society, well functioning international institutions and a rule-based international order' under the umbrella concept of effective multilateralism. The US NSS mentions the UN as one of several mechanisms, along with the WTO, NATO and coalitions of the willing. For the EU, the UN is central, and the UN Charter is 'the fundamental framework for international relations.' While the NSS refers to the US constitution there is no similar mention in the ESS of national or EU constitutions.

Although the EU as such is a strange creature, the conception of order corresponds with what Armin von Bogdandy has identified as the mainstream, an international law of cooperation between sovereign states - for sure, a sovereignty inscribed in and restricted by international law, but sovereignty nevertheless.

${ }^{9}$ This is the upshot of many contemporary analyses, most famously, of course (but not identically), Martti Koskenniemi, From Apology to Utopia: The Structure of International Legal Argument (Helsinki, Finnish Lawyers' Publishing Company 1989) and David Kennedy, International Legal Structures (Baden-Baden, Nomos, 1987).
} 
service, ${ }^{10}$ and on the rhetorical skills and political capital of the legal advisor. In other words, it depends on the legal adviser and on the context in which she is working. Let me begin with the context.

My context is that of a public opinion that is extremely attentive to international law, a government that always declares international law to be a main pillar of its foreign policy, a ministry that often keeps the international law department involved throughout in policy-making, and a culture of respect for international law. In other words: the very hospitable environment of a 'declaratory state'. ${ }^{11}$

Issues that are framed as legal ones are generally respected as such. This pertains to issues dealt with in the UN's legal committee, which are decided by the Legal Department, with only rare interventions from the political departments. When it comes to more 'political' issues - to which there is always a legal side - the lawyers can be both trouble-makers and problem-solvers. In cases where the concrete actions of the government is the issue, the legal advice is almost invariably heeded to (though sometimes a bit grudgingly). In other situations, when questionable behaviour of a third state is at issue, there is a sometimes difficult decision whether or not to emphasise the legal aspects and, perhaps, pay a political prize. ${ }^{12} \mathrm{~A}$ small state might not afford to take a tough and principled position on too many issues. When it comes to highly political and complex issues, like Iraq, 9/11 and Guantánamo, where a legal position is unavoidable, it is interestingly enough sometimes the case that the policy-makers are a bit bewildered before the legal advice comes in, and the final position often is built on that advice. This might be because the legal analysis finds resonance in the not yet articulated hunches at the political side, as a useful point of reference. But I believe that there is also an acute awareness among policymakers that new situations will produce precedents, and that the legal implications of whatever stance they take must be considered very carefully.

Besides the context, there is also the international lawyer herself and how she does international law, her 'approach'.13 One may think of international law as many things. It is a mode of doing foreign policy that is built on the ideas that like shall be treated alike, that everyone is always accountable, that claims should be supported with arguments applicable also to others, etc. Further, international law contains constructive - not only legal but also political -- values and principles, such as the prohibition of the use of force, good neighbourliness, human rights, and so on. Both of these approaches serve to enrich politics qua politics, but they are to a large extent parasitic on the more narrow conception of law as binding norms, which must be retained, too. And in order to impress the instrumentalists, one would have to point at the instrumental usefulness of international law as a tool for foreign policy. So it appears to me that there are at least four approaches to international law: as a mode of doing foreign policy, as values which should form integral parts of foreign policy, but also as a more strict legal framework for foreign policy and as an instrument for other goals of foreign policy. Work at the Ministry, it seems to me, requires that one is able to shift between these four positions. But the choice between them is seldom evident. On the one hand, I have to weigh between strictly legal considerations, principled policy considerations and political considerations, to show that my advice is sensible. But on the other hand, I cannot be too instrumental or too moral, because the political policy-makers often want a strict legal point of view, to allow them to do the political balancing. In some situations, it is more fruitful to use the fairness mode of reasoning or even to discuss world-views, while at other occasions the reference to the

\footnotetext{
${ }^{10}$ Some ministries keep the legal departments involved throughout in policy-making and pay a great deal of attention to international law. In some other ministries the legal people are more detached from policy-making.

${ }^{11}$ This is a reference - doubly ironic - to the candid presentation by former Foreign Minister Hubert Védrine on the first night of the conference.

12 A recent example from my own case-book is the Partnership Fisheries Agreement between the EC and Morocco, which was adopted by the Council of Ministers on 22 May, 2006. During the process leading up to this decision, Sweden had serious concerns as to whether the agreement would be in conformity with international law, since it was supposed to cover also the waters outside Western Sahara, which is not a recognised part of Morocco. Sweden opposed the agreement, while one other Member States abstained. Sweden also submitted a declaration, as did some other member states.

This principled line was determined by several factors, including a vocal and well-informed public opinion in Sweden, but the interesting thing is that it was readily accepted by all branches of the Swedish government, in spite of anticipated and actual resentment in some important foreign capitals.

${ }^{13} \mathrm{I}$ have developed my ideas in this respect at the end of Pål Wrange, 'Downtown, Midtown, Uptown: Review of Louis Henkin, "International Law: Politics and Values" and Thomas M. Franck, "Fairness in International Law and Institutions" (1999) 68 Nordic Journal of International Law 53-83. This section of the present article builds on that earlier piece.
} 
letter of the UN Charter or the UN Covenant on Civil and Political Rights is more to the point, and at yet other times it seems better to rationalise in purely political terms, such as instrumental concern with the legitimacy of the Security Council or the credibility of Swedish foreign policy. What ultimately determines which approach to adopt is the result of one's judgement (a distillate of knowledge, experience, values, ethos etc.) of the particular situation. The outcome is the result of a negotiation between the Grotian cosmopolite and the national bureaucrat in me, ${ }^{14}$ as well as between me and my interlocutors. It is seldom simple, seldom clear-cut, but an answer has to be given, and often very soon.

\section{The General Interest}

Could the outcome of all of this represent the general interest? Will the notion of the general interest even be helpful?

The notion of interest is, of course, not given, but contestable, and it has to be constructed at every 'now and here'.

First of all, who are the subjects with relevant interests? The assumption underlying traditional international law is that it is the state. But that is a very facile assumption and no more than a legal fiction. Very often it is the interests of the regime that is involved - 'the UN as a trade union of leaders'. To take the 'people' as a building block ${ }^{15}$ would not solve the problem. As liberal international law tells us, peoples are made up of many different individuals with diverse interests. ${ }^{16}$ One can, of course, assume that the interest presented by a duly empowered representative of a state is the weighed interest of the state, including its peoples, people and various institutions. This is a practical assumption, but often no more than that. And what about the interests of marginalized or transnational groups, which can not be properly reflected in a national policy process?

Secondly, can interest be ascertained from the conscious volitions of people? In other words, is an interest what someone says that she needs or wants, or is it what she actually needs and should want, if she had made a rational and fully informed choice, her 'interêt veritable' (true interest), to quote Fredrick the Great? ${ }^{17}$ And does that cover also altruistic interests, such as an interest in human rights? To build on the notion of 'interêt veritable', should one inject a value judgment into the notion of interest to form a general, or public interest, distinct from the actual interests of actual people, in line with Rousseau's concept of a volonté générale.

My conclusion, rebuttable for sure, is that the general interest should mean the 'real' interest of an altruistic, enlightened humanity. But assuming that that conception would be acceptable, we still have the third conundrum, namely that general interests, however constructed, may be contradictory, like development and protection of the environment. ${ }^{18}$

Admitting that there is no generally accepted definition of the general interest, and admitting that there is even less of a general acceptance as to the reference of such a definition (i.e., what the general interests are), perhaps the only reasonable way to use the beautiful idea of the general interest is to take it to be whatever comes out of a certain type of deliberation. One can think either in substantive or procedural terms here.

Firstly, as John Rawls suggests, one could make a substantive distinction between public reason ('political values') on the one hand and private, comprehensive value systems on the other. The former

\footnotetext{
${ }^{14}$ As Martti Koskenniemi has expressed it, the international lawyer is caught between the identity of a Grotian cosmopolite and that of a national bureaucrat. Martti Koskenniemi, From Apology to Utopia (Helsinki, Finnish Lawyers' Publishing Company 1989) 490-501. We entered international law because we wanted to do good. But, as we've become professional lawyers, we have had to pay tribute to those who are paying our salaries.

${ }^{15}$ Note that Rawls uses the term 'peoples' only for the 'well-ordered' entities, but uses 'state' in connection with 'outlaw', and 'society' in connection with 'burdened'. This is related to his use of 'people' in ideal theory, while nonideal theory recognizes the existence of political entities that are organised differently. John Rawls, The Law of Peoples with 'The Idea of Public Reason Revisited' (Cambridge, Mass, Harvard University Press, 1999) 23 \& 90.

${ }^{16}$ Slaughter, Anne-Marie. 'International Law in a World of Liberal States' (1995) 6 European Journal of International Law 503 at 508 .

${ }^{17}$ Ernst Wolfgang Orth, 'Hauptakzente des Interessebegriffs vom 16.bis ins 19. Jahrhundert', in in Brunner, Contze \& Koselleck (eds), Geschicbtliche Grundbegriffe III (Klett-Cotta, 1982) 318 at 320. Much legislation in the social field actually proceeds from the assumption that I do not always know what is in my interest. Cf also Cf William E. Connolly, The Terms of Political Discourse (3rd ed., Princeton, Princeton University Press, 1993) 62 et seq.

${ }^{18}$ Brilliant formulas like 'sustainable development' can capture the need to balance the two, but can never do away with the tension.
} 
covers those values that are relevant to political decisions, whereas the other, comprehensive systems such as religious doctrines - in principle should be left out of the political process. The values and arguments that are acceptable in political discourse are only those that can be acceptable to all, not those that derive from any one comprehensive value system. ${ }^{19}$ This condition is probably fulfilled in much of domestic political discourse in many countries, and such and approach is probably the only possible one in international relations. In fact, international law and diplomacy by and large concern to such political values. ${ }^{20}$ It is my experience that in multilateral circumstances we usually do reason in terms of general interests, or at least in terms of interests common to all around the table, probably because the issues are framed in such terms. ${ }^{21}$

Secondly, when it come to the process, one needs to find something not too far from the ideal speech situation that Jürgen Habermas has spent a life-time trying to (re)construct as a procedural basis for what he calls deliberative democracy. ${ }^{22}$ However, as Hauke Brunkhorst has pointed out, there is a difference between a weak public and a strong public, and on the international scene we do have a weak public. ${ }^{23}$ The ideal speech situation will never materialize in international relations, but some things could be done. (In a sense, the EU concept of effective multilateralism - one of the corner-stones of the European Security Strategy - aims at creating conditions that might be conducive to arriving at the general interest.) The whole elaborate architecture of international institutions and conferences with their rules of procedure are, indeed, quite discouraging of talk about particular interests and does legitimise decisions. ${ }^{24}$

Alternatively to international public discourse between all parties concerned, there is the option of a third party decision. Such decisions can, in principle, be taken by an international court or by a political body, such as the UN Security Council. ${ }^{25}$

So, a formulation of a general interest can be arrived at either through a discussion conducted through certain rules or by a decision of a legitimate third party. And reasoning in terms of the general interest excludes arguments of power. Still, such a 'general interest' will not be embraced by everyone, as

${ }^{19}$ John Rawls, The Law of Peoples with 'The Idea of Public Reason Revisited' (Cambridge, Mass, Harvard University Press, 1999) 54 et seq, 134 et seq and passim.

${ }^{20} \mathrm{I}$ tend to think of these procedures as intimately linked to Western ways of thinking. I would hesitate, though, to give the West all credit for these generally useful arrangements. Many Third World writers have traced various aspects of international law to their respective indigenous or regional systems. As Amartya Sen points out with regard to the values of freedom and democracy, what we think of as the fine Western heritage is, in fact, just one stream of many in Western thought, and many of the same ideas that we relish can be found also in other traditions. See Amartya Sen, Development as Freedom (New York Anchor Books, 1999) 232 et seq.

21 These common interests are constructed differently at different times, though. In public speeches in formal meetings, delegates often appeal to the general interest of humanity, or of the represented states. In informal meetings, where much of the work is done, it is more common to invoke the common professional interest of the present delegates to 'get the work done', preferably on time. A delegate may in such situations be a bit more frank about what would be politically possible in her capital, and the assumption here is that other delegates might assist the speaking delegate in achieving a result that she can defend back home. More direct 'power talk' is usually heard only in direct contacts between delegates in the corridors or in private settings. Unless the negotiations are very charged, such 'arguments' would be considered inappropriate around the multilateral table, and therefore necessary to cover in other terms.

Cf also the observations from a many with a perspective different from mine, Hans J. Morgenthau, Politics Among Nations: The Struggle for Power and Peace (3rd ed, New York, Alfred E. Knopf, 1961) 494.

22 See Jürgen Habermas, Faktizität und Geltung (4th ed, Frankfurt, Suhrkamp, 1994) 367 et seq.

23 A strong public has political, administrative and moral power. The weak international public lacks enforcement, but still has at least moral influence. See Hauke Brunkhorst, 'Globalising Democracy Without a State: Weak Public, Strong Public, Global Constitutionalism’ (2002) 31 Millenium 675.

24 Procedural rules are, of course, important. But it is equally important to avoid that some interests are being prejudiced because they are governed by weaker procedures than other interests. For instance, the rules on trade fair or not - have strong enforcement procedures, whereas others, which deal with potentially contradicting interests - labour, the environment, etc - have much weaker procedures. Another similar case is the relation between antiterrorism - high on the UN Security Council's agenda - and international humanitarian law. In fact, it could be said that in a case of a collision between different regimes, the forum actually determines the outcome.

${ }^{25}$ Of course, it is quite rare that none of the leading powers on the Council has a national interest - in the usual sense of that word - when a 'situation' is dealt with. This does not, however, mean that the Council never acts in line with a plausible conception of the general interest. 
explains Chantal Mouffe. ${ }^{26}$ Antagonism and enmity will not evaporate in the conference room. And any formulation of the general interest will probably exclude some views, some people, and be counter to some particular interests. ${ }^{27}$

In fact, I find it hard detect many widely accepted general interests of the international society, even in a thin sense. One may be survival or development, another one the integrity of international law (although some might say that felicity to international law is but one 'special interest' among many others. And as soon as those general interests are supposed to be concretized, the equation becomes almost impossible. To stop climate change is surely a general interest, but the issue might just as well be reduced to a number of particular and conflicting interests, between hot and cold, dry and wet, poor and rich countries. ${ }^{28}$ Similarly, while peace is certainly a general interest, in any situation of violence, there will be contrasting interests - in Central Africa, in the Middle East, etc - because there are different notions of what a peace should look like.

Further, the general interest is a utilitarian principle, since Jeremy Bentham. ${ }^{29}$ And utilitarians may use one person - or one group - as a means rather than as an end. ${ }^{30}$ Is it right to sacrifice the interests of one people seeking self-determination, in order to stop a destabilizing regional conflict? It may, in fact, be right to let the particular interests win over the 'general interest', because a moral choice has privileged that interest.

\section{International Law and the General Interest II}

Fraught with conceptual and practical difficulties, 'general interest' still has a value. Like 'justice', 'general interest' is a regulative idea with a normative force. It is further a discursive locus, a common place. If I refer to my interests, my arguments are not really open to question - after all, who can tell me what my interests are? By contrast, to speak in terms of the general interest entails that one opens up the discussion, because everyone is a legitimate stakeholder in the general interest. However, while the notion of general interest might be useful at the level of norms, it will not be helpful in a concrete case. It needs to be complemented with the notion of justice, concrete justice. ${ }^{31}$

There is an institution, which is oriented to concrete justice and not to instrumentalism, to general interests at the normative level but not in casu: International law. Regardless of whether the international lawyer acts as a spokesperson for the national or the general interests, her language will be accessible to others. Just like the Rawlsian notion of public reason, international law accepts only some arguments as valid. Further, it has procedures that provide an opportunity for secular and detached, yet flexible debates. The lawyer sees his role as a lawyer, and has to defend her views before other lawyers in a language of experts. Political advisers generally respect the specificity of this discourse and often acknowledge its usefulness, I suggest. In addition, with all their weaknesses, the conventions which provide the working

\footnotetext{
${ }^{26}$ Chantal Mouffe, The Return of the Political (London, Verso, 1993) 141-142 and passim and Chantal Mouffe, 'Deliberative Democracy and Agonistic Pluralism' (paper, Institute for Advanced Studies, Vienna, 2000) 13.

${ }^{27} \mathrm{It}$ is probably completely unnecessary to invoke the concept of the general interest when it is embraced by everyone.

${ }^{28} \mathrm{I}$ am not sure at all that I, who live in a cold country, would be worse off with a slightly warmer climate. And in deciding whether the developing countries should bear as large part of the burden of cutting down on the emission of green-house gases as the developed ones, the notion of general interest is not very helpful. Justice seems more to the point. (And having said that, I have revealed my own position on the matter.)

${ }^{29}$ This conception of the general interest is, though, different from conceptions of interests of collective entities. Kelly points out the difference between the amorphous 'common good' and Bentham's 'greatest happiness of the greatest number’. J.M. Kelly, A Short History of Western Legal Theory (Oxford, Clarendon Press, 1992) 287-288.

${ }^{30}$ For a criticism of utilitarianism on this point, see, i.a., John Rawls, The Law of Peoples with 'The Idea of Public Reason Revisited' (Cambridge, Mass, Harvard University Press, 1999) 40.

31 The concept of justice is, of course, no less problematic than 'general interest'. A conception of justice is necessary to formulate rules and principles of general application, and it is therefore sometimes difficult to distinguish from the general interest. What I am after here is the notion that the concrete decision has to respond to a demand for justice in a concrete situation, however that demand be phrased. A proper response to such a demand cannot only invoke the general utility of the rule that is being applied, but must address the situation at hand. See, for example, Costas Douzinas and Ronnie Warrington, Justice Miscarried: Ethics, Aesthetics and the Law (New York, Harvester Weatsheaf, 1994) 231.
} 
material for the lawyer do constitute formulations of what states have agreed to be their common interests. Perhaps it is even impossible to determine a general interest 'bors de la loi', outside the law.

While exclusive and 'terribly unjust', 32 international law is better than the alternative - power politics. We know that the content of international law is not always fair, because the people who made the law were not always determined to make it fair, and would not have accepted it if it had been. ${ }^{33}$ However, it is more likely that a weak party will win a legal argument than a political fight. Benevolent hegemons are very rare.

So where does this leave the international lawyer? ${ }^{34}$

In a recent article, Peter J. Spiro finds that globalisation brings tremendous opportunities for international lawyers. 'Indeed international law is now positioned to be a first-mover in both the law and the social sciences', even to acquire 'dominance'. ${ }^{35}$ But we are not elected. US conservatives warn that 'international law is quickly being transformed into a transnational sovereign without legitimation by the governed, ... an empire of the scholars. ${ }^{36}$ As David Kennedy points out, international lawyers do, indeed, participate in political decisions, by supplying background norms, judgments and advice.

The lawyer is trained to answer the question 'what is valid law?', but international law is not only a system of valid law which has to be frozen every time that question is to be answered. It is also a developing system, and the lawyers, as actors, take part in that development. There are no independent observers, at least not in the legal profession. And one thing sets international law apart: The invocation of law is purported to be, and is sometimes accepted as, a conclusive argument -- a show-stopper. So we have to act responsibly.

But how to do that, when we are always surrounded by controversy? We could probably do worse than turn to Immanuel Kant here. In his third Critique, the Critique of Judgment, Kant explains that taste is that which cannot be based on anything, but which still commands agreement. ${ }^{37}$ That is exactly how we talk about international law, I believe. And in his second Critique, the Critique of Practical Reason, he outlines what I believe to be the really relevant concept of interest for the international lawyer, namely a disinterested and a higher interest that could produce a law and a decision. ${ }^{38} \mathrm{~A}$ call for agreement without proof, a devotion to law but not to the parties -- that should be the basis of our judgment.

What does this mean in practice? In the Middle East, the justice of the situation and the general interest in the norms at stake point in the same direction: Terrorism is wrong and unlawful, to take the territory of another people is wrong and unlawful. This makes the legal adviser's job (relatively) easy. ${ }^{39}$

\footnotetext{
32 David Kennedy asks 'how the discipline participates in keeping a terribly unjust international order up and running' David Kennedy, 'When Renewal Repeats: Thinking Against the Box' (2000) 32 New York. University Journal of International Law and Politics 335 at 456. The bitterness in many parts of the world for the present, institutionalised order of things is, of course, not unjustified. For one piece of eloquent anger, with which I agree to a large extent, see B.S. Chimni, 'International Institutions Today: An Imperial Global State in the Making (2004) 15 European Journal of International Law 1.

${ }^{33}$ Hedley Bull, The Anarchical Society: A Study of World Order in World Politics (New York, Columbia University Press, 1977) 92 .

${ }^{34} \mathrm{I}$ have developed some of the following thoughts a bit in Pal Wrange, 'The Prince and the Discourse: On Commenting and Advising on International Law', in Jarna Petman \& Jan Klabbers (eds) Nordic Cosmopolitanism: Essays for Martti Koskenniemi (Leiden, Martinus Nijhoff, 2003) 33-47.

35 Peter J. Spiro, 'Globalization, International Law, and the Academy' (2000) 32 New York University Journal of International Law and Politics 567 at 587 and 590.

${ }^{36}$ Andy Olson, 'An Empire of the Scholars: Transnational Lawyers and the Rule of the Opinio Juris' (2000) 29

Perspectives on POLITICAL SCIENCE, Winter, 23, 23, accessed at

$<<$ ben.aubg.bg/Courses/fall2001/pos312/46.htm>> on 15 March, 2006. .

${ }^{37}$ I suggested this idea in a presentation at the Swedish Academy of Fine Arts in 1993-94. Some ten years later, I came across the same concept - in relation to 'public reason' -- in Alessandro Ferrara, 'Public Reason and the Normativity of the Reasonable’ (manuscript on file with the author, 2002) 18. See Immanuel Kant, Kritik der Urteilskraft (3rd ed Frankfurt, Suhrkamp, 1997) 127, 157-158.

${ }^{38}$ Immanuel Kant, Kritik derpraktischen Vernunft (3rd ed, Frankfurt, Suhrkamp, 1997) 84 et seq. To mix up these two ideas, which refer to different faculties, might be a too great liberty, philosophically speaking.

${ }^{39}$ I.e., it is easy from a policy perspective with regard to the issues that I find to be the main ones, namely the settlements, the Barrier and terrorism. Nevertheless, there are some very difficult legal and policy issues in the Middle East conflict, most of which concern the responses by the IDF (Israeli Defence Forces) to alleged (and too often real) acts and threats of terrorism. Many of these difficulties are technical, in the sense that they turn on the facts. But there are also some very complex substantive issues, such as the threshold for an armed conflict.
} 
In Kosovo in 1999, the calculation was more difficult. Concrete justice seemed to demand a military intervention. But, at the general level, what was the most important norm involved - the prohibition of force or the duty to promote human rights? Was it in the general interest to say that the bombings were illegal, to find a nascent norm of humanitarian intervention, or perhaps to say that respect for norms may have to be sacrificed for the justice of the situation? Although the military action was conclusive, the legal discussion was not. But in distinction to the bombing campaign, the discussion was conducted in open terms, with arguments accessible to all, including the policy-makers - the languages of the general interest, justice and of law. The question 'what general interest?' seemed impossible to determine, while the concrete case opened up the argument: Whose interests? What justice?40

The issue whether a decision to use force for the enforcement of UNSC resolutions against Iraq could be taken by any government or just by the Security Council involved the interpretation of a lot of UNSC Resolutions and state practice. In the end it came down to a policy choice, I believe: What sort of UN do we want? What sort of international system do we want?

While I think that international law often speaks in favour of what I find to be general interests, that is far from always the case, and there may be legal arguments for both the particular and the general interest as well as for more than one competing or contradicting general interest. As a lawyer I deal with these conflicts in a professional manner. However, in situations where the product of the political vectors is uncertain, the law is often less clear. In such cases, I will have to resort to policy-arguments, based both on the telos of the legal rules and the policy-choices between various interests.

There is a piece of territory between being an advocate for an interest (general or specific) and being 'la bouche de la loi', the mouth that simply pronounces the law (Montesquieu). One has to both be open to the malleability of international law and respect its specificity. But no formula can tell us how to do both of those things, how to orient in that strip of land, or how to take account of the values and interests in the general norm and the justice of the concrete situation. All one has is one's judgment. And one cannot say much more than that.

\footnotetext{
40 See the discussions in, e.g., (1999) 10 European Journal of International Law, no. 1 and 4 and (2001) 12 European Journal of International Law, no. 3, (1999) 93 American Journal of International Law, no. 3 and No 4 (1999); (2000) Revue internationale de la Croix-Rouge, March 2000, no. 837, (2000) 104 Revue général du droit international public, no. 1 (2000) and (1999) 47 NATO Review, no. 3.
} 